\title{
KUTATÁSI IRÁNYVONALAK A MISKOLCI EGYETEM ELEKTRO- TECHNIKAI ÉS ELEKTRONIKAI INTÉZETI TANSZÉKÉN
}

\author{
Bodnár István \\ intézeti tanszékvezetö egyetemi docens, Miskolci Egyetem, Fizikai és Elektrotechnikai Intézet, \\ Elektrotechnikai és Elektronikai Intézeti Tanszék \\ 3515 Miskolc, Miskolc-Egyetemváros, e-mail: vegybod@uni-miskolc.hu \\ Somogyiné Molnár Judit \\ egyetemi docens, Miskolci Egyetem, Fizikai és Elektrotechnikai Intézet, \\ Elektrotechnikai és Elektronikai Intézeti Tanszék \\ tudományos fömunkatárs, MTA-ME Müszaki Földtudományi Kutatócsoport, Miskolci Egyetem \\ 3515 Miskolc, Miskolc-Egyetemváros, e-mail: gfmj@uni-miskolc.hu
}

\begin{abstract}
Absztrakt
A tanulmány a Miskolci Egyetem Elektrotechnikai és Elektronikai Intézeti Tanszékén folyó kutatási irányvonalakat mutatja be. A tanszéki kutatások nem csak elméleti, azaz alapkutatások, hanem alkalmazott kutatások is. Az alapvetöen négy témakört (Villamosenergia-termelés környezetközpontú értékelése; Globális optimalizációs adatfeldolgozás; BLDC motorok EMC vizsgálata; Napszimulátorok, valamint napelemek kisérleti és szimulációs vizsgálata) átfogó kutatás-fejlesztési program szervesen kapcsolódik az aktuális ipari kérdéshez is, így elmondható, hogy a Tanszéken jövőbe mutató kutatómunka folyik.
\end{abstract}

Kulcsszavak: kutatási program, erömüvek LCA-elemzése, globális optimalizációs adatfeldolgozás, napelem, BLDC motor EMC vizsgálata,

\begin{abstract}
This paper presents the research directions of the Department of Electrical Engineering and Electronics of the University of Miskolc. The departmental research is not only theoretical, i.e., basic research, but also applied research. The research and development program covers basically four topics (Environment-oriented assessment of electricity production; Global optimization data processing; EMC testing of BLDC motors; Experimental and simulation testing of solar simulators and solar cells) is related to the current industrial issue, so it can be said that the Department does forward-looking research work.
\end{abstract}

Keywords: research program, LCA analysis of power plants, global optimization data processing, solar panel, EMC testing of BLDC motor

\section{Bevezetés}

A Miskolci Egyetem Elektrotechnikai és Elektronikai Intézeti Tanszéke számos olyan kutatási irányvonalon müveli a müszaki tudományosságot, amelyek nem csak az elméleti, hanem az alkalmazott kutatásokhoz is szorosan kapcsolódnak. A kutatási irányok érintik a villamosenergia-termelés környezeti hatásainak értékelését, a megújuló és a hagyományos energiaforrások és erőműveik elemzését; a napelemek üzemeltetési problémáit, amely problémák a napelemes erömü hatékonyságát és élettarta- 
mát csökkenti; a napelemről táplált villamos hajtásokat, ahol elsődlegesen a különböző villamos paraméterekkel rendelkező villamosenergia hatékony és dinamikus átalakítása a cél. Szorosan kapcsolódik a villamos gépek és hajtások, valamint teljesítményelektronikai egységeik elektromágneses kompatibilitási vizsgálata, valamint a méréstechnika és a globális optimalizációs adatfeldolgozás.

\section{Villamosenergia-termelés környezetközpontú értékelése}

Magyarország 2019-ben 33.075,15 GWh villamosenergiát termelt. A fogyasztás 45.660,51 GWh volt. A 12.585,35 GWh különbséget importból fedeztük. Ez azt jelenti, hogy a hazai villamosenergiafogyasztás $72,44 \%$-t tudtuk megtermelni és $27,56 \%$-át fedeztük más nemzetek termeléséből [MAVIR adatszolgáltatási felülete alapján]. A hazai termelésủ villamosenergia 87,65\%-a hagyományos erőmüvekből származott és csak a 12,35\%-a megújuló energiaforrásokból.

Az 1. ábra az egyes erőmüvek karbon-lábnyomát szemlélteti $1 \mathrm{kWh}$ villamosenergia elóállítására vonatkoztatva szén-dioxid-egyenérték kibocsátásban mérve a teljes életciklus szemlélet mellett. Megfigyelhető, hogy az atomerőmüvek karbonlábnyoma a legkisebb $\left(4,68 \mathrm{gCO}_{2}\right.$-egyenérték/kWh). A második legkisebb szén-dioxid-egyenértékü üvegházhatást okozó gázkibocsátással a vízerőmüvek rendelkeznek, a mintegy 5,49 $\mathrm{gCO}_{2}$-egyenérték/kWh értékkel. Ezt követik a szélerőművek $(10,1)$, a biomassza $(57,5)$ és a napelemes $(65)$ erőmüvek. A legnagyobb kibocsátás a lignittüzelésủ erőmünél tapasztalható (1.340 $\mathrm{gCO}_{2}$-egyenérték/kWh). A hulladéktüzelésủ (szilárd települési hulladék) (621 $\mathrm{gCO}_{2}$-egyenérték/kWh) erőművek a gáztüzelésű, valamint a lignit/szén és olaj tüzelésű $\left(970 \mathrm{gCO}_{2}\right.$ egyenérték/kWh) erőművek között helyezkednek el. Magyarországon $1 \mathrm{kWh}$ villamosenergia elöállítása 2019-ben átlagosan $317 \mathrm{gCO}_{2}$-egyenértékủ üvegházhatású gáz kibocsátással járt. Ezek alapján elmondható, hogy amennyiben ettől kisebb kibocsátással termelő erőmüvek (atom, víz, szél, napelem, biomassza és biogáz) hosszútávú üzemeltetésében gondolkodunk, akkor a villamosenergiatermelés karbon-lábnyoma jelentősen csökkenthető.

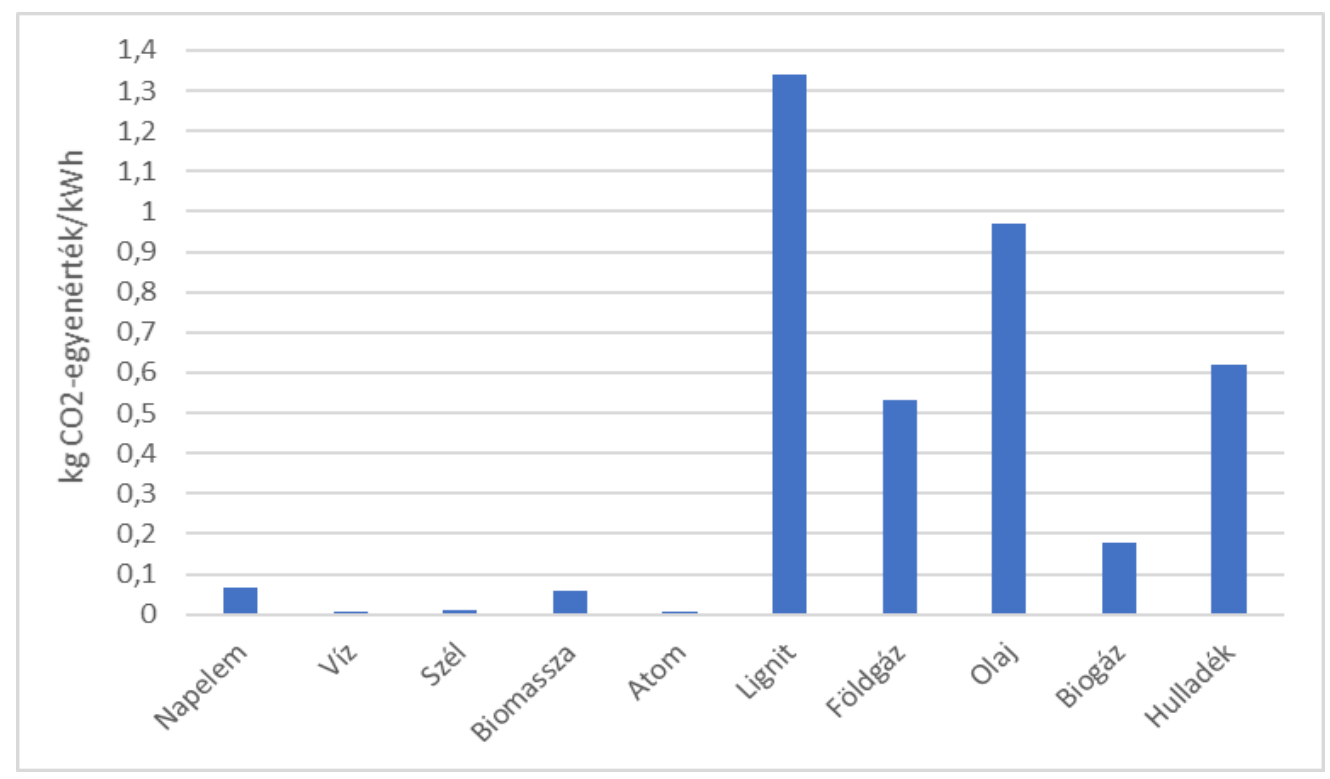

1. ábra. Erömüvek karbon-lábnyoma szén-dioxid-egyenértékben kifejezve, életciklusszemlélettel. 
Ugyan a hazai termelésủ villamosenergia 2019-ben átlagosan $317 \mathrm{gCO}_{2}$-egyenértékủ üvegházhatású gáz kibocsátással járt, ezzel ellentétben a hazai felhasználású villamosenergia ugyan ebben az évben $401 \mathrm{gCO}_{2}$-egyenértéket képviselt. A hazai hagyományos erőmüvek a kibocsátott üvegházhatású gázok 94,95\%-ért felelősek, míg csak a maradék 5,06\% származik a megújuló forrásokat alkalmazó erőmüvekből.

A fosszilis energiaforrások kimerülése tekintetében a hazai termelésü villamosenergia 3,88 MJ értéket képvisel $1 \mathrm{kWh}(3,6 \mathrm{MJ})$ villamosenergiára vonatkoztatva. Ez azt jelenti, hogy egységnyi villamosenergia-előállítása során attól nagyobb mennyiségü fosszilis energiahordozóra van szüksége. A hazai fogyasztású villamosenergiánál ez a különbség még szembe tűnőbb, értéke 4,16 MJ. Ennél a környezeti hatáskategóriánál 7,22\% a különbség. Mindezek azt az állítást erösítik meg, hogy az import energia jellemzően hagyományos energiaforrásokból, kiemelten szén-, lignit-, olaj- és/vagy földgáztüzelésủ erőművekből származott. Viszonyítási alapként az Európai Unió országainak átlaga: 416 gCO2egyenérték és 4,47 MJ. Svájc esetén ezek az értékek $162 \mathrm{gCO}_{2}$-egyenérték és 1,5 MJ.

Alapfeltevés, hogy 2030-ra a Paks II projekt megvalósul és a mostani atomerőmü sem kerül leállításra, vagyis az atomerőmüvek kapacitása $2 \mathrm{GW}$-ról 4,4 GW-ra emelkedik. Mindemellett a napelemes erőművek a jelenleg üzemelő $1 \mathrm{GW}$-os kapacitása $6 \mathrm{GW}$-ra bővül és a Mátrai Erőmű pedig leállításra kerül. Amennyiben más energiaforrások termelése nem változik, ellenben a villamosenergiafogyasztás $20 \%$-kal bővül, akkor a hazai termelés a hazai fogyasztás 97,33\%- át tudja fedezni, azaz a külföldi függőség tizedére csökken. Amennyiben a tervezett beruházások megvalósulnak akkor a Magyarországon termelt villamosenergia karbonlábnyoma 2030-ban $107 \mathrm{gCO}_{2}$-egyenérték/kWh értékre csökken. A 2019-es évhez képest ez 66,25\%-os csökkenést jelent. A fosszilis energiaforrások kimerülésére gyakorolt hatás a 2019. évhez képest 2030-ban akár 56,96\%-kal is kisebb lehet, azaz 1,67 $\mathrm{MJ} / \mathrm{kWh}$ értékre csökken. Ennek megvalósulása esetében csökkenteni lehet a fosszilis energiahordozók kimerülésének ütemét. Azonban nem szabad figyelmen kívül hagyni, hogy a klasszikus atomerömüvek üzemeltetéséhez szükséges 235 tömegszámú urán a becslések szerint 120-135 évre elegendö mennyiségben áll rendelkezésre, így azok kimerülésével is számolnunk kell a XXII. Században, így még sürgetőbb alternatív energiaforrások felfedezése és bevonása az energiatermelésbe.

\section{Globális optimalizációs adatfeldolgozás}

Laboratóriumokban gyakran vizsgált és fontos jelenség a különböző frekvenciájú rugalmas hullámok eltérő közegekben történő terjedése és csillapodása. A rugalmas hullám terjedési jellemzőit síkhullámú közelítésben az elmozdulás-függvény kifejezésében a (veszteséges közegben) komplex hullámszám jellemzi, melynek valós része a közegben terjedő akusztikus hullám fázissebességével van kapcsolatban, képzetes része pedig az abszorpciós tényező. A rugalmas hullám csillapodásának jellemzésére az abszorpciós tényező mellett szokásos a jósági tényező definiálása is, mellyel fordított arányosságban áll. Az akusztikus hullám mért sebességének vagy jósági tényezőjének adatait többféleképpen dolgozhatjuk fel. Például a laboratóriumban mért nyomás-jósági tényező adatokat linearizált optimalizációs eljárással. Azonban ez a módszer a paraméterekre nem a legjobb becslést adja, mert a lokális minimumban elakadhat, ezért fontos az adatok globális optimalizációs feldolgozásának vizsgálata. Különböző adatrendszereken vizsgáltuk és sikeresen teszteltük a globális minimumot adó eljárások közül a Metropolis-algoritmust alkalmazó Simulated Annealing eljárást (MSA).

Az MSA eljárást a fémek hütésének analógiája alapján Metropolis és társai dolgozták ki. A legtöbb esetben a minimalizálandó célfüggvényt - az MSA terminológiájában energiafüggvényt - a mért és számított adatok eltérésének L2 normája alapján definiáljuk. A módszer lényege, hogy az optimalizá- 
lás során az algoritmus véletlen keresést hajt végre a paramétertérben, miközben a modellparaméter vektor elemeit iterációról iterációra véletlenszerüen változtatja. Az eljárás így adott hőmérsékleten különböző véletlen energiaállapotokat (modelleket) próbál ki, a véletlen keresés során az aktuális számított energiafüggvényt az előző iterációs lépésben elfogadott energiafüggvénnyel összehasonlítja és minden iterációs lépésben elöállítja a $\Delta E$ energia eltérést. Az új modellparamétervektor elfogadása feltételhez kötött, ez a Metropolis kritérium: az új modellt mindig elfogadjuk, ha az energiafüggvény az új iterációs lépésben kisebb az előzőhöz képest $(\Delta \mathrm{E} \leq 0)$. Ha növekszik a mért és számított adatok eltérése. $(\Delta \mathrm{E} \geq 0)$ az eljárás akkor is definiál elfogadási valószínüséget, mellyel a lokális minimumból való kiszabadulást biztosítja. Ha teljesül $\mathrm{P}(\Delta \mathrm{E}, \mathrm{T})=\exp (\Delta \mathrm{E} / \mathrm{T}) \geq \alpha$ feltétel, akkor az új paramétervektort fogadjuk el ( $\alpha$ egyenletes valószínüséggel generált $[0,1]$ intervallumba eső szám). Ellenkező esetben természetesen elvetjük azt. Az előbbi formulában a $T$ hőmérsékletet (kontrollparamétert) megfelelő ütemben iterációról iterációra csökkenteni kell. Az eljárást addig ismételjük, amíg a megfelelő stop kritérium teljesül. Számításainkhoz ezt az algoritmust MATLAB kódban valósítottuk meg. Természtesen az MSA algoritmust nemcsak az akusztikus hullám csillapodásával kapcsolatban álló nyomás-jósági tényező adatok, hanem más típusú adatrendszerek esetében is lehet alkalmazni.

\section{BLDC motorok EMC vizsgálata}

A Tanszék utóbbi éveiben jelentősen erősödött az elektronikus kommutációjú, kefe nélküli egyenáramú motorok (BLDC) elektromágneses sugárzásának kutatása. Az Elektromágneses összeférhetőség (EMC) egyre nagyobb hangsúlyt kap nem csak az iparban, hanem a mindennapi használati eszközöknél is. Jelen kutatómunkánk során egy autómotorhütő ventilátor BLDC motorjának EMC központú fejlesztésében veszünk részt. A cél a motor elektromágneses sugárzásának minél hatékonyabb csökkentése, hogy az meg tudjon felelni a jövőben várhatóan szigorodó elöírásoknak is. A kutatómunka során egy árnyékolt laborban (Faraday Kalicka) végzünk méréseket, ahol a referencia modulok, valamint a fejlesztés során átalakított modulok EMC zajkibocsátását mérjük. A 2. ábra szemléltet egy vizsgált modult és a méréshez használt antennát.

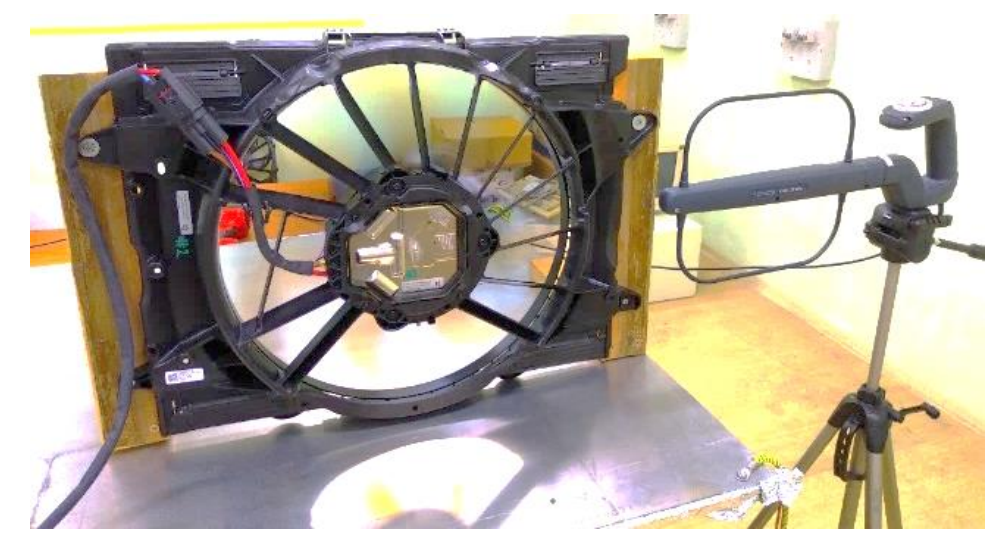

2. ábra. Egy vizsgált modul és a mérés során használt antenna.

A kutató-fejlesztő munka során különböző csapágyak, hagyományos és villamosan vezető csapágyzsírok, EMC hálók, vasmagállórészek és vezérlő áramkörök mérése történt meg. Mivel a klasszikus botantenna helyett irányított antennával végeztük a méréseket, ezért sikerült lokalizálni, hogy mely egységek, alkatrészek felelősek a nagyobb EMC zajkibocsátásért, így a fejlesztés eddigi eredmé- 
nyeként sikerült olyan megoldásokat találnunk, amelyek jelentősen, akár 30-70\%-kal is csökkentik az elődtermék EMC zajkibocsátását, valamint a gyakorlatban is alkalmazhatók.

\section{Napszimulátorok, valamint napelemek kísérleti és szimulációs vizsgálata}

Napelemek laboratóriumi vizsgálatához Napszimulátor, vagy fényszimulátor szükséges. Ilyen eszközzel lehet biztosítani az azonos mérési körülményeket. Az első generációs napfényszimulátorok halogén-, xenon- vagy egyszerü volfrámszálas fényforrásokon és azok kombinációján alapulnak. A félvezető technológia fejlődésével új típusú napfényszimulátorok jelennek meg, amelyek nagyteljesítményü LED egységeket alkalmaznak. Ezen eszközök müködése energiahatékony és jó irányíthatóság jellemzi őket, továbbá különböző színü LED egységek kombinációjával a napfény spektrális szerkezete jól közelíthető velük. Hátrányként említhető azonban, hogy tisztán LED egységeket alkalmazva nehéz elérni a szabványos vizsgálatokhoz szükséges $1000 \mathrm{~W} / \mathrm{m}^{2}$ fényintenzitás értéket. E problémát küszöbölik ki a LED és hagyományos megvilágítást (pl.: halogén) kombináló megoldások.

A napfényszimulátorokra érvényes követelményekkel az American Standard for Testing and Materials (ASTM) E972-es (IEC 60904-9) szabványa foglalkozik. Kutató-fejlesztő munkánk során e szabvány szerinti $C$ osztályú napfényszimulátor készítése történt meg, amely segítségével maximálisan 150 mm x $150 \mathrm{~mm}$ méretủ napelem cella megfelelő megvilágítása vált lehetségessé. A konstrukció a nagyteljesítményű színes LED egységek és halogén izzók kombinációján alapul. Az elkészült berendezést és egy napelemcella mérést a 3 . és 4 . ábra szemlélteti.
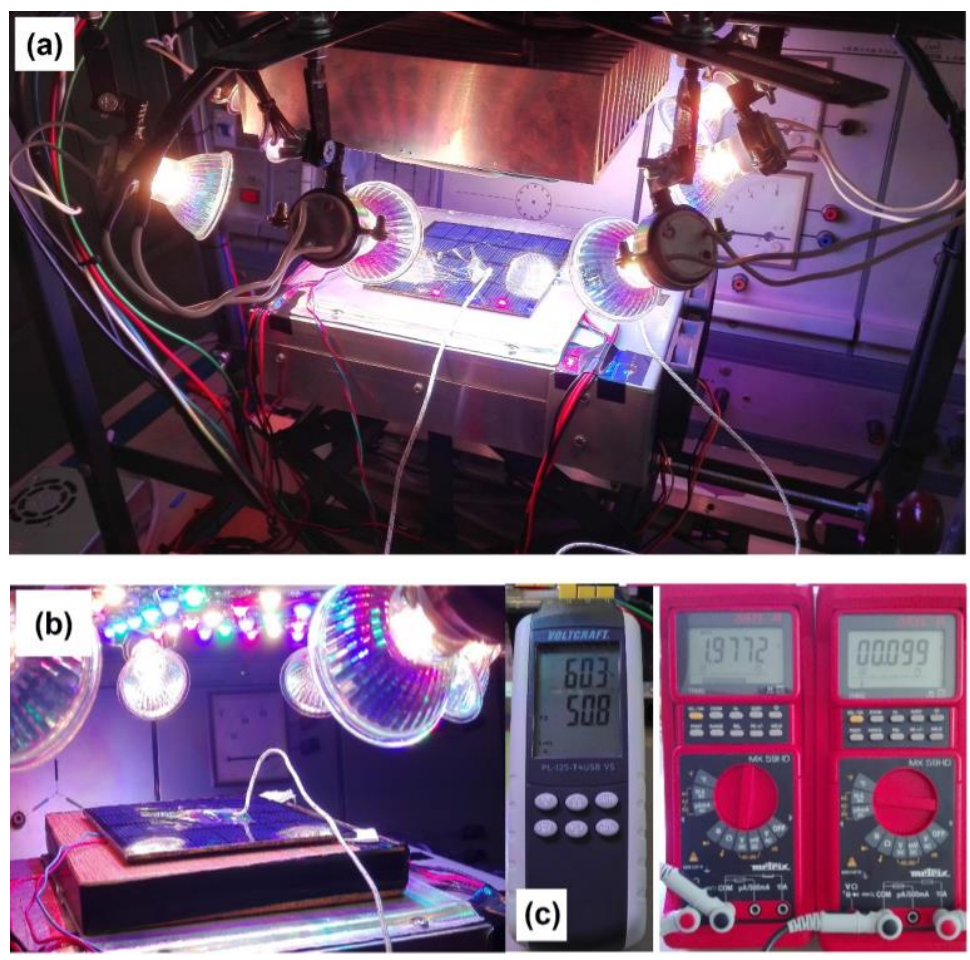

3. ábra. Mérési összeállitás (a), a mért cella (b), valamint a hömérséklet, a feszültség és az áramerösségmérö (c). 
A szimulációkat MATLAB szoftver segítségével végeztük. Vizsgálataink során nem csak a napelemek állandó hőmérsékleten, hanem a tranziens jelenségek során történő villamosparaméterek változását is vizsgáltuk. A mérési eredményekre alapozva pontosítottuk a szimulációsmodellt. Az alapmodellhez képest a módosított modell pontatlansága kevesebb, mint a felére csökkent.

További kutatási irányvonal a napelemek felületén lerakodó szennyeződések okozta hatásfok- és élettartamcsökkenés képviseli. Laboratóriumi vizsgálatok során különbözö természetes és mesterséges eredetü porok és szennyezőanyagok hatásait vizsgáltuk. Az árnyékhatás okozta termeléskiesés mellett a napelem hőmérsékletének növekedésével is számolnunk kell. Az egyes porok és szennyezőanyagok igencsak eltérö hatást gyakorolnak a napelemek müködésére. A koszos napelemek hömérséklete, akár $50{ }^{\circ} \mathrm{C}-\mathrm{kal}$ is nagyobb lehet, mint a tiszta napelemeké. A tartósan szennyezett napelemek károsodnak, élettartamuk rohamosan csökken, amely jellemzően a mikrorepedések megjelenésében, azok tovább növekedésében, és a napelemet borító üveglap felületi morfológiájának a megváltozásában jelentkezik. A károsodás elkerülése érdekében a felületi szennyeződések eltávolítására tisztítás módszerek alkalmazása válik szükségessé.

\section{6. Összefoglalás és következtetések}

Összességében elmondható, hogy a Miskolci Egyetem Elektrotechnikai és Elektronikai Intézeti Tanszékén folyó kutatások nem csak elméleti, azaz alapkutatások, hanem alkalmazott kutatások is. Az irányvonalak érintik az aktuális ipari kérdéseket, így jövőbe mutató kutatás-fejlesztő munka folyik. A folyóiratban bemutatott kutatási eredmények számos folyóirat és konferencia cikkben kerültek bemutatásra [1-11].

\section{Köszönetnyilvánítás}

A cikkben ismertetett kutató munka az EFOP-3.6.1-16-2016-00011 jelü „Fiatalodó és Megújuló Egyetem - Innovatív Tudásváros - a Miskolci Egyetem intelligens szakosodást szolgáló intézményi fejlesztése" projekt részeként - a Széchenyi 2020 keretében - az Európai Unió támogatásával, az Európai Szociális Alap társfinanszírozásával valósul meg.

\section{Irodalomjegyzék:}

1. Bodnár, I.: Simulation of acacia gasification process. Review of Faculty of Engineering Analecta Technica Szegedinensia 14. 2020. 1. pp. 24-33. https://doi.org/10.14232/analecta.2020.1.24-33

2. Bodnár, I.: Napelemes kiserőmü feszültségviszonyai a hőmérséklet-változás függvényében. ELEKTROTECHNIKA 113 évf. 2020. 5-6. sz. pp. 13-17.

3. Bodnár, I., Boros, R. R., Matusz-Kalász, D.: Solar powered electric car with VVVF drive control. GÉP. 71. évf. 2020. 3-4. sz. pp. 55-60.

4. Bodnár, I., Koós, D., Iski P., Skribanek, Á.: Design and Construction of a Sun Simulator for Laboratory Testing of Solar Cell. Acta Polytechnica Hungarica. Óbuda Univesity. Budapest, Hungary, Vol. 17. No. 3. 2020. pp. 165-184. https://doi.org/10.12700/APH.17.3.2020.3.9

5. Somogyiné Molnár, J., Kiss, A., Dobróka, T. E.: Global joint inversion of acoustic velocity and quality factor data using rock physical models. Geosciences and Engineering, 6. kötet, 9. szám, 2019. pp. 151-162. 
6. Somogyiné Molnár, J., Kiss A., Dobróka, T. E., Jobbik, A.: Akusztikus sebesség és jósági tényező adatok globális együttes inverziós feldolgozása kőzetfizikai modellek alapján. Müszaki tudomány az Észak-kelet Magyarországi Régióban 2019 konferencia kiadvány, pp. 337-340.

7. Bodnár, I.: Napelemcella laboratóriumi vizsgálata. Multidiszciplináris Tudományok. Miskolci Egyetem kiadványa. 9. kötet. 2019. 4. sz. pp. 242-249. https://doi.org/10.35925/j.multi.2019.4.21

8. Bodnár, I., Matusz-Kalász, D.: Napelemek laboratóriumi és szimulációs vizsgálata. Multidiszciplináris Tudományok. Miskolci Egyetem kiadványa. 9. kötet. 2019. 4. sz. pp. 261-268. https://doi.org/10.35925/j.multi.2019.4.23

9. Faragó, D., Bodnár, I., Bencs P., Koós, D., Iski, P., Skribanek, Á.: Laboratory measurements and numeric simulation of a solar cell. 2019 20th International Carpathian Control Conference (ICCC). 2019. p. 6. Doc Nr. 105. (IEEE) https://doi.org/10.1109/CarpathianCC.2019.8765927

10. Bodnár, I., Csehi B., Sukály B., Gáspár Á. Cs.: Examination of power loss and voltage drop of a solar panel as a function of environmental factors. 2019 20th International Carpathian Control Conference (ICCC). 2019. p. 5. Doc Nr. $107 . \quad$ (IEEE) https://doi.org/10.1109/CarpathianCC.2019.8765911

11. Bodnár, I., Faragó, D., Dojcsák, Gy.: Simulation of a solar power plant. 2019 20th International Carpathian Control Conference (ICCC). 2019. p. 6. Doc Nr. 146. (IEEE) https://doi.org/10.1109/CarpathianCC.2019.8766044 